\title{
Comparative Effect of Cecal Ligation and Colostomy on Nitrogen Utilization in Chickens Fed Low Protein or Urea-Supplemented Low Protein Diets.
}

\author{
Jang-Ho Son and Yutaka Karasawa \\ Laboratory of Animal Nutrition and Feed Science, Faculty of Agriculture, Shinshu University, \\ Minamiminowa-Mura, Nagano-Ken 399-45, Japan.
}

\begin{abstract}
A study was carried out to investigate nitrogen metabolism in response to cecal ligation and colostomy in chickens. We used colostomized plus ceca-ligated chickens fed a low protein diet or a low protein diet supplemented with urea. When both types of diets were fed, nitrogen balance and utilization tended to increase by cecal ligation while total nitrogen excretion tended to decrease. Colostomy increased total nitrogen excretion and decreased nitrogen balance and utilization in chickens fed both types of diets. Therefore, total nitrogen excretion, nitrogen balance and utilization were significantly different between the ceca-ligated and colostomized chicken fed both types of diets $(P<0.05)$. Cecall ligation tended to decrease urinary nitrogen excretion in chickens fed a low protein diet and significantly decreased it in chickens fed the low protein diet supplemented with urea $(\mathbf{P}<0.05)$, but did not change fecal nitrogen excretion in chickens fed both types of diets. Total uric acid excretion and urinary uric acid excretion were decreased by cecal ligation $(P<0.05)$ but increased by colostomy $(P<0.05)$ in chickens fed both types of diets. When a low protein diet supplemented with urea was fed, total urea excretion was significantly higher in colostomized than in other three groups $(\mathrm{P}<0.05)$, and urinary urea excretion in colostomized chickens was significantly decreased by cecal ligation $(\mathrm{P}<0.05)$. Total ammonia excretion was significantly higher in ceca-ligated chickens than those of three other groups fed the low protein diet supplemented with urea $(\mathrm{P}<0.05)$, but was similar in the four groups when the low protein diet was given. This indicates that ceca in chickens fed protein-deficient diets may have two different roles in nitrogen utilization : the urine nitrogen retrograded from the cloaca into the ceca is beneficial, but ingesta nitrogen from the small intestine into the ceca is not so. Therefore, collectively chicken ceca could have a negative effect in nitrogen utilization in the chicken regardless of having a significant recovery of urinary nitrogen through ceca.
\end{abstract}

Key words : chicken, nitrogen balance, low protein diet, urea, cecal ligation, colostomy

\section{Introduction}

Previous studies have indicated the possibility that nitrogen balance is improved by

Received : January, 21, 2002, Accepted : November 8, 2002

To whom correspondence should be addressed.

Dr. Jang-Ho Son Department of Animal Science, College of Natural Resources, Taegu University, Gyongsan city, kyongbook, South Korea.

E-mail : shinshu@chollian.net 
cecal ligation in chickens fed a low protein diet or a low protein diet supplemented with urea, and the improvement is explained mainly by a significant decrease in uric acid excretion (Son et al., 1996 a ; Karasawa et al., 1997). It was also shown that colostomy reduced nitrogen balance in chickens fed a low protein diet or a low protein diet supplemented with urea, and the reduction was explained mainly by a significant increase in uric acid excretion (Karasawa et al., 1989 ; Karasawa and Maeda, 1992). This suggests different effects of cecal ligation or colostomy on nitrogen metabolism when fed a low protein diet or low protein diet supplement with urea.

The cecal contents is filled by two routes. One is the small particles of ingesta from small intestine (Björnhag and Sperber, 1977 ; Skadhauge, 1981), and the other is the urinary and digestive fluids retrograded from the colon (Akester et al., 1967 ; Fena and Boag, 1974 ; Son et al., 2002). In colostomized birds, ceca are filled only by digesta from the small intestine, while ceca filling does not occur in ceca-ligated birds.

Our previous study with ceca-ligated and colostomized chickens fed a low protein diet or a low protein diet supplemented with urea has suggested that ceca play a beneficial role in nitrogen utilization of the chicken when there is back flow of urine from the cloaca to the ceca (Karasawa, 1989 ; Karasawa and Maeda, 1992), but not when digesta flow into the ceca from the ileum (Son et al., 1996 a ; Karasawa et al., 1997 ; Son and Karasawa, 2000).

The objective of the present study was to investigate the effect of complete inhibition of both urine back flow and the cecal filling from the ileum on the utilization of dietary nitrogen. This was done using both colostomy and cecal ligation in chickens fed a low protein or urea-supplemented low protein diet.

\section{Material and Methods}

\section{Animals and treatment}

Seventeen-month-old Single Comb White Leghorn cockerels weighing $2.20 \pm 0.03$ (mean \pm SEM) $\mathrm{kg}$ were used. The birds were individually housed in metabolism cages in a room light-controlled (14L-10D) and maintained at $20 \pm 1.5^{\circ} \mathrm{C}$. The control chickens were sham-operated in the same manner as in the ceca-ligated and colostomized chickens except for the cecal ligation and colostomy, respectively. Surgeries for cecal ligation and colostomy were performed according to the method of Son et al. (1996 a, b) and Okumura (1976), respectively. Prior to surgery, the birds were fasted for $12 \mathrm{~h}$ and anesthetized with sodium pentobarbital $(25 \mathrm{mg} / \mathrm{kg}$ body weight $)$ via the wing vein. The ceca were ligated with a nylon thread (Gin-rin, No $1.5 \phi, 0.205 \mathrm{~mm}$ ) as near as possible to the cecal origin and an artificial anus was made in the colon. A small amount of Sulfisomidinum (Iwaki Pharmaceutical Co, Tokyo) was sprinkled into the abdominal cavity of the chicken, and abdominal muscular layers and skin were successively sutured. Two months after each operation, the chickens were used for experiments. Post-mortem inspections were done on all the ceca-ligated chickens to ascertain the completeness of the ligation.

Diets

A 5\% protein semi-purified, pellet type diet which contained egg albumen as a sole 
source of protein was prepared as described previously (Karasawa et al., 1973). The experimental chickens were fed $35 \mathrm{~g}$ of the diet per $\mathrm{kg}$ body weight per day in the morning ( $08: 30$ ) for $7 \mathrm{~d}$ or supplied $10 \mathrm{~m} l$ of $6 \%$ urea solution $(60 \mathrm{~g} / \mathrm{L}$ distilled water) per $\mathrm{kg}$ body weight per day by intubating into the crop after $5 \mathrm{~g}$ of the $5 \%$ protein semi-purified diet had been consumed. Thus, both daily nitrogen intake of the 5\% protein diet ( $35 \mathrm{~g} / \mathrm{kg}$ body weight) and $280 \mathrm{mg}$ of urea per $\mathrm{kg}$ body weight were insured. Sample collection and analytical methods

The feces and urine mixture, feces and urine were collected for the last $2 \mathrm{~d}$ of the each experimental period, using a polyethylene bag attached to the cloaca and artificial anus, respectively. The collected excreta were immediately weighed, sprayed with 5\% $\mathrm{HCl}$ (vol/vol), and then dried in an electric oven with forced aeration at $55^{\circ} \mathrm{C}$ for $48 \mathrm{~h}$.

Nitrogenous compounds were extracted from a given amount of the dried excreta in $0.5 \%$ lithium carbonate solution. Total nitrogen in excreta was determined by a Kjeldahl method, uric acid in blood and excreta by enzymatic spectrophotometric methods (Pudelkiewicz et al., 1968), urea in blood and excreta by a urease method (McNabb and McNabb, 1975), and ammonia in blood and excreta by colorimetric methods (Okuda and Fujii, 1966 ; McNabb and McNabb, 1975).

Data were statistically analyzed by one-way analysis of variance and Tukey's test (Steel and Torrie, 1960).

\section{Results}

Daily body weight changes of control, ceca-ligated, colostomised and colostomised plus ceca-ligated chickens were, respectively, $-1.9 \pm 1.8,-0.1 \pm 1.1,-6.4 \pm 4.2$ and $0.4 \pm 5.0 \mathrm{~g}$ fed a low protein diet and $-2.2 \pm 1.6,0.2 \pm 1.2,-3.8 \pm 8.3$ and $-0.7 \pm 3.7 \mathrm{~g}$ fed a low protein diet supplemented with urea : none of these differences was significant.

The effects of colostomy plus ceca-ligation on nitrogen excretion, balance and utilization in chickens fed the low protein diet or the low protein diet supplemented with urea are shown in Tables 1 and 2. When both types of diets were fed, total nitrogen excretion tended to decrease by cecal ligation (compared with control, colostomized or

Table 1. Effect of colostomy and caecal ligation on nitrogen balance and utilization in chickens fed a low protein diet (Nitrogen $\mathrm{mg} / \mathrm{kg}$ body weight/day)

\begin{tabular}{|c|c|c|c|c|c|}
\hline & Control & Caeca-Ligated & Colostomized & $\begin{array}{c}\text { Colostomy plus } \\
\text { Ligation }\end{array}$ & SEM \\
\hline Intake & 280.0 & 280.0 & 280.0 & 280.0 & \\
\hline \multicolumn{6}{|l|}{ Excretion } \\
\hline Feces & & & 47.6 & 47.1 & 2.2 \\
\hline Urine & & & 216.6 & 184.7 & 10.3 \\
\hline Total & $234.7^{\mathrm{ab}}$ & $216.7^{\mathrm{a}}$ & $264.2^{\mathrm{b}}$ & $238.8^{\mathrm{ab}}$ & 7.2 \\
\hline Balance & $45.3^{\mathrm{ab}}$ & $63.3^{\mathrm{a}}$ & $15.8^{\mathrm{b}}$ & $41.2^{\mathrm{ab}}$ & 7.2 \\
\hline Utilization $(\%)$ & $16.2^{\mathrm{ab}}$ & $22.6^{\mathrm{a}}$ & $5.6^{\mathrm{b}}$ & $14.7^{\mathrm{ab}}$ & 4.1 \\
\hline
\end{tabular}

Values are means of 6 chickens.

${ }^{a, b}$ Means in the same row with no common superscript differ significantly $(\mathrm{P}<0.05)$. 
Table 2. Effect of colostomy and caecal ligation on nitrogen balance and utilization in chickens fed a low protein diet supplemented with urea (Nitrogen $\mathrm{mg} / \mathrm{kg}$ body weight/day)

\begin{tabular}{|c|c|c|c|c|c|}
\hline & Control & Caeca-Ligated & Colostomized & $\begin{array}{c}\text { Colostomy plus } \\
\text { Ligation }\end{array}$ & SEM \\
\hline Intake & 560.0 & 560.0 & 560.0 & 560.0 & \\
\hline \multicolumn{6}{|l|}{ Excretion } \\
\hline Feces & & & 61.9 & 59.8 & 3.3 \\
\hline Urine & & & $458.3^{\mathrm{a}}$ & $406.9^{b}$ & 9.3 \\
\hline Total & $384.5^{\mathrm{a}}$ & $332.9^{\mathrm{a}}$ & $520.2^{\mathrm{b}}$ & $466.7^{\mathrm{b}}$ & 13.9 \\
\hline Balance & $175.5^{\mathrm{a}}$ & $227.0^{\mathrm{a}}$ & $39.8^{\mathrm{b}}$ & $93.3^{\mathrm{b}}$ & 13.9 \\
\hline Utilization $(\%)$ & $31.3^{\mathrm{a}}$ & $40.5^{\mathrm{a}}$ & $7.1^{\mathrm{b}}$ & $16.7^{\mathrm{b}}$ & 3.8 \\
\hline
\end{tabular}

Values are means of 6 chickens.

${ }^{\mathrm{a}, \mathrm{b}}$ Means in the same row with no common superscript differ significantly $(\mathrm{P}<0.05)$.

colostomized plus ceca-ligated chickens). Therefore, nitrogen balance and utilization tended to increase by cecal ligation, because nitrogen intake was the same in the four groups on either diet. When the low protein diet supplemented with urea was fed, colostomy increased total nitrogen excretion $(P<0.05)$, and thus significantly decreased nitrogen balance and utilization $(P<0.05)$ compared with that in other three groups. Similar responses were obtained in chickens fed on the low protein diet. Total nitrogen excretion and balance tended to decrease and increase, respectively, by colostomy in ceca-ligated chickens fed both types of diets. Therefore total nitrogen excretion, balance and utilization were significantly different between the ceca-ligated and colostomized chickens fed both types of diets $(\mathbf{P}<0.05)$. Urinary nitrogen excretion tended to increase by cecal ligation in colostomized chickens fed the low protein diet, and increased $(\mathrm{P}<0.05)$ by cecal ligation in colostomized chickens fed the low protein diet supplemented with urea. Fecal nitrogen excretion was not changed by cecal ligation in colostomized chickens regardless of diet.

Tables 3 and 4 present the effect of colostomy plus ceca-ligation on the excretion of nitrogenous compounds into urine and feces in chickens fed the low protein diet or the low protein diet supplemented with urea. Total uric acid excretion and urinary uric acid excretion were decreased by cecal ligation regardless of diet $(\mathrm{P}<0.05)$. However, total uric acid and urinary uric acid were significantly increased by colostomy $(P<0.05)$. When fed the low protein diet supplemented with urea, total urea excretion was increased only in the colostomized chickens $(P<0.05)$, and urinary urea excretion was significantly decreased by cecal ligation in colostomized plus ceca-ligated chickens. When the low protein diet was fed, total urea excretion was significantly decreased in ceca-ligated chickens compared with colostomized ones. Total ammonia excretion was much higher in the ceca-ligated chickens than in those of other three groups fed the low protein diet supplemented with urea $(\mathrm{P}<0.05)$. But when the low protein diet was fed, total ammonia excretion was same in the four groups. Uric acid, urea and ammonia excretions in the feces were not changed significantly by cecal ligation in the colostomized chickens fed both types of diets. 
Table 3. Effect of colostomy and caecal ligation on excretion of nitrogenous compounds in urine and feces in chickens fed a low protein diet (Nitrogen $\mathrm{mg} / \mathrm{kg}$ body weight/day)

\begin{tabular}{lccc}
\hline \hline & Urine & Feces & Total \\
\hline Uric acid & & & \\
Control & & & $110.2^{\mathrm{a}}$ \\
Caeca-Ligated & $179.5^{\mathrm{a}}$ & 4.1 & $69.7^{\mathrm{b}}$ \\
Colostomized & $137.4^{\mathrm{b}}$ & 2.2 & $183.6^{\mathrm{c}}$ \\
Colostomy plus Ligation & 12.3 & 0.7 & $139.6^{\mathrm{a}}$ \\
SEM & & & 11.7 \\
Urea & & & $12.3^{\mathrm{ab}}$ \\
Control & & & $8.9^{\mathrm{a}}$ \\
Caeca-Ligated & 9.8 & 5.3 & $14.1^{\mathrm{b}}$ \\
Colostomized & 1.8 & 4.1 & $13.2^{\mathrm{ab}}$ \\
Colostomy plus Ligation & & 0.8 & 1.9 \\
SEM & & & 33.0 \\
Ammonia & & & 32.2 \\
Control & 24.6 & 6.2 & 30.7 \\
Caeca-Ligated & 29.6 & 8.9 & 38.5 \\
Colostomized & 2.4 & 0.8 & 1.6 \\
Colostomy plus Ligation & & & \\
SEM & & & \\
\hline
\end{tabular}

Values are means of 6 chickens.

${ }^{\mathrm{a}, \mathrm{b}, \mathrm{c}}$ Means in the same column with no common superscript differ significantly $(\mathrm{P}<0.05)$.

Tables 5 and 6 represent the effect of colostomy plus ceca-ligation on concentrations of blood nitrogenous compounds in chickens fed the low protein diet or low protein diet supplemented with urea. None of blood uric acid, urea and ammonia concentration was significantly changed by any treatment in either dietary group.

\section{Disussion}

In agreement with previous results (Karasawa, 1989 ; Karasawa and Maeda, 1992 ; Son et al., 1996 a ; Karasawa et al., 1997 ; Son and Karasawa, 2000), the nitrogen balance was increased and decreased by cecal ligation and colostomy, respectively, when fed a low protein diet or a low protein diet supplemented with urea. In addition, the present experiment first demonstrated that cecal ligation in colostomized chickens also enhanced nitrogen balance in chickens fed a low protein diet or a low protein diet supplemented with urea.

Protein-depleted chickens can recover urinary nitrogen through the back flow of urine from the cloaca into the ceca (Karasawa and Maeda, 1994). As the ceca-ligated or colostomized plus ceca-ligated chickens prevent the entry of the both ingesta and urine into the ceca, the present results indicate that the entry of ingesta into the ceca in protein-depleted chickens may have an adverse effect on nitrogen utilization : this would appear to be larger than the beneficial effect caused by the back flow of urine into the ceca. Cecal ligation in the chicken resulted in a decreased uric acid excretion, 
Table 4. Effect of colostomy and caecal ligation on excretion of nitrogenous compounds in urine and feces in chickens fed a low protein diet supplemented with urea (Nitrogen $\mathrm{mg} / \mathrm{kg}$ body weight/day)

\begin{tabular}{lccc}
\hline \hline & Urine & Feces & Total \\
\hline Uric acid & & & \\
Control & & & $139.0^{\mathrm{a}}$ \\
Caeca-Ligated & $260.7^{\mathrm{a}}$ & 6.3 & $108.6^{\mathrm{a}}$ \\
Colostomized & $181.8^{\mathrm{b}}$ & 7.3 & $267.0^{\mathrm{c}}$ \\
Colostomy plus Ligation & 8.0 & 0.6 & $189.1^{\mathrm{b}}$ \\
SEM & & & 8.8 \\
Urea & & & $62.8^{\mathrm{a}}$ \\
Control & & & $80.5^{\mathrm{a}}$ \\
Caeca-Ligated & $73.5^{\mathrm{b}}$ & 6.9 & $128.9^{\mathrm{b}}$ \\
Colostomized & 5.8 & 7.1 & $80.6^{\mathrm{a}}$ \\
Colostomy plus Ligation & & 1.3 & 5.9 \\
SEM & & & $59.5^{\mathrm{a}}$ \\
Ammonia & & & $83.3^{\mathrm{b}}$ \\
Control & 59.9 & 10.0 & $69.9^{\mathrm{a}}$ \\
Caeca-Ligated & 62.2 & 7.3 & $69.0^{\mathrm{a}}$ \\
Colostomized & 4.0 & 0.8 & 3.7 \\
Colostomy plus Ligation & & & \\
SEM & & & \\
\hline
\end{tabular}

Values are means of 6 chickens.

${ }^{a, b, c}$ Means in the same column with no common superscript differ significantly $(\mathrm{P}<0.05)$.

Table 5. Effect of colostomy and caecal ligation on concentrations of blood nitrogenous compounds in chickens fed a low protein diet

\begin{tabular}{lccccc}
\hline \hline & Control & Caeca-Ligated & Colostomized & $\begin{array}{c}\text { Colostomy plus } \\
\text { Ligation }\end{array}$ & SEM \\
\hline Uric acid $(\mathrm{mg} / 100 \mathrm{~m} l)$ & 3.8 & 2.4 & 3.0 & 2.2 & 0.5 \\
Urea $(\mathrm{mg} / 100 \mathrm{~m} l)$ & 1.0 & 0.5 & 1.3 & 0.7 & 0.3 \\
Ammonia $(\mu \mathrm{g} / \mathrm{m} l)$ & 4.3 & 4.3 & 4.5 & 4.4 & 0.6 \\
\hline
\end{tabular}

Values are means of 6 chickens.

Table 6. Effect of colostomy and caecal ligation on concentrations of blood nitrogenous compounds in chickens fed a low protein diet supplemented with urea

\begin{tabular}{lrcccc}
\hline \hline & Control & Caeca-Ligated Colostomized & $\begin{array}{c}\text { Colostomy plus } \\
\text { Ligation }\end{array}$ & SEM \\
\hline Uric acid $(\mathrm{mg} / 100 \mathrm{~m} l)$ & 4.2 & 4.2 & 3.6 & 2.9 & 0.6 \\
Urea $(\mathrm{mg} / 100 \mathrm{~m} l)$ & 53.2 & 78.0 & 60.5 & 54.0 & 5.9 \\
Ammonia $(\mu \mathrm{g} / \mathrm{m} l)$ & 6.3 & 5.8 & 6.1 & 5.2 & 0.3 \\
\hline
\end{tabular}

Values are means of 6 chickens. 
contributing to an increase in nitrogen balance and utilization.

It is also suggested that cecectomy improves nitrogen utilization by decreasing urinary uric acid excretion in growing chicks and adult chickens (Son et al., 1997 ; Son et al., 2000). In addition, when a $10 \%$ protein diet or a $14 \%$ protein diet was fed to chickens (Son et al., 1996 b ; Son et al., 1998), cecal ligation improved nitrogen utilization by decreasing urinary uric acid excretion. It is possible, therefore, that the improvement of nitrogen balance and utilization by cecal ligation is mainly derived from the remarkable decrease in uric acid formation in chicken body, since the excretion of nitrogenous compounds other than uric acid is appreciably unchanged in the cecal ligated chickens. These responses were in agreement with cecal ligation in colostomized chickens (Karasawa, 1989 ; Karasawa and Maeda, 1992 ; Son et al., 1996 a ; Karasawa et al., 1997 ; Son and Karasawa, 2000).

The increase in volume of ligated cecal contents with time indicated that some microbial activity must have continued. It is possible that nutrients could have entered the cecal lumen from the blood (Mortensen and Tindall, 1984 ; Poppema and Duke, 1992 ; Son and Karasawa, 2000). By assuming possible changes in fermentation through ligation of ceca, there is a disadvantage in leaving the ligated ceca in the abdominal cavity, and consequently a removal of cecal contents in ceca-ligated chickens improves nitrogen utilization and decreases uric acid excretion (Son and Karasawa, 2000).

In the domestic fowl, urinary compounds are transported from the cloaca into the ceca (Koike and McFarland, 1966 ; Akester et al., 1967 ; Son et al., 2002) and ingesta also by the flux from the small intestine into the ceca (Björnhag, 1989). The colostomy prevents the back flow of urine, but not flux from the small intestine into the ceca. The cecal ligation prevents the latter, but not the former, i.e., urine entering the colon and the ileo-cecal-colic junction (Poppema and Duke, 1992). The present results obtained in the colostomized plus ceca-ligated chicken showed that nitrogen utilization and balance were decreased by colostomy and the decrease was reduced by cecal ligation. It may imply that chicken ceca have different roles in nitrogen utilization. When the urine nitrogen from the cloaca retrograded into the ceca, the role of ceca is beneficial, but when ingesta nitrogen from the small intestine flows into the ceca, nitrogen utilization is reduced. The extent was bigger in the latter than the former from the present results. These suggest collectively that chicken ceca have a negative effect in nitrogen utilization in the chicken although it recovers a significant amount of urinary nitrogen through the ceca.

Dietary urea can be utilized in chickens when crystalline amino acid diets low in nonessential nitrogen or diets containing low concentrations of intact protein are fed (Featherston et al., 1962 ; Chavez and Thomas, 1969 ; Lee and Blair, 1972 ; Davis and Martindale, 1973). In the present study, the addition of urea to a low protein diet increased nitrogen balance up to $130-160 \mathrm{mg}$ in the control and ceca-ligated chickens, suggesting that dietary urea is utilized in these chickens. Karasawa (1999) demonstrates that there is a urinary nitrogen recovery system through ceca in the chicken and it is involved in utilization of dietary urea. According to it dietary urea is absorbed 
intact at the upper intestine, the absorbed urea is excreted into urine, carried back into the ceca along with urine by means of antiperistalsis and hydrolyzed into ammonia by cecal microorganisms, and the ammonia is utilized for nonessential amino acid synthesis. In the present experiment colostomy decreased nitrogen utilization in both control and ceca-ligated chickens fed a low protein diet supplemented with urea. This finding supports the involvement of urinary nitrogen recovery system through ceca in the utilization of dietary urea in the chicken.

Cecal ligation tended to enhance nitrogen utilization in both control and colostomized chickens. This enhancement was accompanied by depressing urinary urea excretion in urea-fed chickens. It is unknown why and how urinary urea excretion is significantly decreased by cecal ligation in colostomized chickens fed the low protein diet supplemented with urea. Further studies are needed to elucidate it.

\section{Acknowledgments}

The authors are indebted to Dr. Olayiwola Adeola (Purdue University) for reviewing this manuscript.

\section{Refernces}

Akester AR, Anderson RS, Hill KJ and Osbaldiston GW. A radiographic study of urine flow in the domestic flow. British Poultry Science, $8: 209-212.1967$.

Bjönhag G and Specber I. Transport of various food components through the digestive tract of turkey, geese and guinea fowl. Swedish Journal of Agricultural Research, 7 : 57-66. 1977.

Björnhag G. Transport of water and food particles through the avian ceca and colon. Journal of Experimental Zoology (Suppl.), 3 : 32-37. 1989.

Chavez $\mathrm{R}$ and Thomas JM. The utilization of non-protein nitrogen by laying hens. Poultry Science, $45: 547-553.1969$.

Davis RH and Martindale CH. The performance of laying hens fed on rearing and laying diets containing urea. British Poultry Science, 14 : 153-160. 1973.

Featherston WR, Bird HR and Harper AE. Effectiveness of urea and ammonium nitrogen for the synthesis of dispensable amino acids by the chick. Journal of Nutrition, $78: 198-206.1962$.

Fenna L and Boag DA. Filling and emptying of the galliform caeca. Canadian Journal of Zooltechnology. 52 : 537-540. 1974.

Karasawa Y, Tasaki I, Yokota $\mathrm{H}$ and Shibata F. Effect of infused glutamine on uric acid synthesis in chickens fed high and low protein diets. Journal of Nutrition, $103: 526-529.1973$.

Karasawa Y. Effect of colostomy on nitrogen nutrition in the chicken fed a low protein diet plus urea. Journal of Nutrition 119 : 1388-1391. 1989.

Karasawa $\mathrm{Y}$ and Maeda M. Effect of colostomy on the utilisation of dietary nitrogen in the fowl fed on a low protein diet. British Poultry Science, 33 : 815-820. 1992.

Karasawa $\mathrm{Y}$ and Maeda $\mathrm{M}$. Role of caeca in the nitrogen nutrition of the chicken fed on a moderate protein diet or a low protein diet plus urea. British Poultry Science, 35 : 383-391. 1994.

Karasawa Y. Son JH and Koh K. Ligation of caeca improves nitrogen utilisation and decreases urinary uric acid excretion in chickens fed on a low protein diet plus urea. British Poultry Science, $38:$ :439-441. 1997.

Karasawa Y. Significant role of nitrogen recycling system through the ceca occurs in proteindepleted chickens. Journal of Experimental Zoology, 283 : 418-425. 1999.

Koike TI and McFarland LZ. Urography in the unanaesthetized hydropenic chicken. American Journal of Veterinary Research, 27 : 1130-1133. 1966.

Lee DJW and Blair R. Effect on chick growth of adding various non-protein nitrogen source or 
dried autoclaved poultry manure to diets containing crystalline essential amino acids. British Poultry Science, 13 : 243-249. 1972.

McNabb FMA and McNabb RA. Proportion of ammonia, urea, urate and total nitrogen in avian urine and quantitative methods for their analysis on a single urine sample. Poultry Science, 54 : 1498-1505. 1975.

Mortensen A and Tindall AR. The role of urea in nitrogen excretion and cecal nitrogen metabolism in willow ptarmigan. Journal of Comparative Physiology, 155B : 71-74.

Okuda $\mathrm{H}$ and Fujii S. Determination of blood ammonia by the spectrophotometric method. Saishin Igaku, $21: 622-627$. 1966. (In Japanese).

Okumura J. Method of colostomy and cannulation of the chicken. British Poultry Science, 17 : 547-551. 1976.

Popema TF and Duke GE. The effectiveness of ligation or detaching ceca as an alternative to cecectomy. Poultry Science, $71: 1384-1390.1992$.

Pudelkiewicz WJ, Stutz WW and Matterson LD. Determination of uric acid in avian excreta by use of uricase and differential spectrophotometry. Poultry Science, 47 : 1274-1277. 1968.

Skadhauge E. Osmoregulation in birds. In : Farner DS. (ed), Zoophysiology, Vol 12. Springer, Berlin Heidelberg New York, pp 1-203. 1981.

Son JH, Karasawa Y and Koh K. Comparative effect of ligation of ceca on nitrogen utilization and nitrogen excretion in chickens fed a low protein diet or a low protein diet plus urea. Animal Science and Technology, 67 : 171-174. 1996 a.

Son JH, Karasawa Y and Koh K. Effects of ligation of ceca on nitrogen utilization and nitrogen excretion in chicken fed a moderate protein diet or a moderate protein diet plus urea. Japanese Poultry Science, 33 : 193-197. 1996 b.

Son JH, Karasawa Y and Nahm KH. Effect of cecectomy on nitrogen utilization and nitrogen excretion in chickens fed a low protein diet supplied with urea. Asian-Australasian Journal of Animal Sciences, $10: 274-276.1997$.

Son JH, KarasawaY and Nahm KH. Comparative effects of cecum-ligation on nitrogen utilization in chickens fed a $5 \%, 10 \%$ and $14 \%$ protein diet. The $8^{\text {th }}$ world conference on Animal production, Vol. 1. 172-173. 1998.

Son JH and Karasawa Y. Effect of removal of cecal contents on nitrogen utlisation and nitrogen excretion in caecally ligated chickens fed on a low protein diet supplemented with urea. British Poultry Science, 41 : 69-71. 2000.

Son JH, Karasawa Y and Nahm KH. Effect of caecectomy on growth, moisture in excreta, gastrointestinal passage time and uric acid excretion in growing chicks. British Poultry Science, $41: 72-74.2000$.

Son JH, Ragland D and Adeola O. Quantification of digesta flow into the caeca. British Poultry Science, in press. 2002.

Steel RG and Torrie H. Principles and procedures of statistics, (New York, McGrow-Hill) 1960. 